\title{
Coeliac disease, gluten-free diet, and malignancy
}

\author{
G. K. T. HOLMES, P. L. STOKES, T. M. SORAHAN, PATRICIA PRIOR, \\ J. A. H. WATERHOUSE, AND W. T. COOKE 1
}

From the Nutritional and Intestinal Unit, The General Hospital, Birmingham, and the Department of Social Medicine, University of Birmingham, Birmingham

SUMmARY Two hundred and two patients with coeliac disease or idiopathic steatorrhoea previously reported from this unit have been reviewed after a further 10 years of follow-up. Of 20 more deaths, 10 were due to malignancy. A separate study was made of all patients with histologically confirmed coeliac disease seen to the end of 1972 and followed up to the end of 1974 . Twenty-one of the 43 deaths in this series were due to malignant tumours, of which 13 were reticulum cell sarcomas. There was no evidence that patients showing sub-optimal clinical response to gluten withdrawal or persisting flat jejunal biopsies were more prone to die of cancer. A gluten-free diet did not appear to be effective in preventing malignant complications, but a longer follow-up of patients will be necessary to provide a final answer to this question.

An association between steatorrhoea and intestinal lymphoma has been recognised since reports by Golden (1936) and Fairly and Mackie (1937). The malabsorption of fat was attributed by early workers either to diffuse infiltration of the gut wall by tumour (Fairly and Mackie, 1937; Salvesen and Kobro, 1939), or to blockage of the small bowel lymphatics by enlarged neoplastic lymph nodes (Golden, 1936). However, Bjerkelund (1950) proposed that abnormalities in the small intestinal mucosa itself were at least partly responsible for the malabsorption observed in three cases of intestinal lymphoma. Several other authors have also described the association (Harrison et al., 1947; Oehler, 1953; Sleisenger et al., 1953; Friedlander and Gorvy, 1955; French et al., 1957; Upshaw and Pollard, 1957; Best and Cook, 1961; Scudamore, 1961). Up to this time, the steatorrhoea in every case was considered to occur secondarily to the lymphoma. However, Read and his colleagues (Gough et al., 1962) suggested that the intestinal reticulosis was a complication rather than a coincidental association with coeliac disease and postulated that the mucosal lesion in this disorder might be a premalignant condition. This concept was supported by other reports (Spracklen, 1963; Barrett, 1964; Missen, 1966), and was considerably strengthened by further observations from Bristol (Austad et al., 1967). The increase in lymphoma was shown to be statistically

\footnotetext{
${ }^{1}$ Address for reprint requests: Dr W. T. Cooke, General Hospital, Steelhouse Lane, Birmingham B4 6NH.

Received for publication 14 May 1976
}

valid by Harris et al. (1967) in a review of 202 patients with coeliac disease in Birmingham.

Malignancy, however, has not been confined to lymphoma. Thus the reports of the 15 patients with adenocarcinoma of the jejunum have been reviewed by Petreshock et al. (1975), while Harris et al. (1967) found that the incidence of gastrointestinal carcinoma was significantly increased, particularly oesophageal carcinoma in men.

Some doubt as to the primary nature of coeliac disease in the association with malignancy was expressed by Creamer (1964). He suggested that malignancy in any part of the body might be associated with villous atrophy, though others in checking jejunal biopsies in patients with malignancy have failed to support this suggestion (Girdwood 1964; Fischer et al., 1965). Nevertheless, Brunt et al. (1969) in reviewing small bowel tumours seen over a period of 10 years again raised the possibility that malignancy itself was the cause of the villous changes encountered in some patients. 'Widespread infiltration or destruction of bowel wall may also cause malabsorption but alteration of villous structure at sites outside the areas of the bowel affected by malignant disease could also lead to deranged function'. They suggested that 'either villous atrophy represents a fundamental change in mucosal stability associated with or predisposing to malignancy or that villous atrophy can be directly produced by malignancy'.

Barry and Read (1973) also expressed some reservations concerning the significance of mucosal 
changes when considering 18 patients in whom they had undertaken mucosal cell turnover studies and who had the characteristic biopsy findings of coeliac disease. The loss rate of DNA was significantly less in the 10 patients who responded poorly to a gluten-free diet, suggesting that they had a 'hypoplastic mucosa' and that the process by which the mucosal abnormality was produced might be different from that of uncomplicated coeliac disease-for example, malignancy which had developed in five of these patients. They pointed out, however, that patients who had responded to a gluten-free diet might later fail to respond to the diet and that therefore mucosal turnover studies might have important prognostic implications. However, no more of the 10 patients have as yet developed malignancy (Read, 1976). Barry et al. (1973) also suggested that some patients with a flat biopsy might have developed this change as a result of infiltration of the mucosa by malignant cells and, by inference, that some patients presenting with lymphoma and a flat biopsy and the features of a malabsorption syndrome were not suffering from coeliac disease.

Criticism can be made of the series reported by Harris et al. (1967) that many of their cases, having died before the introduction of the technique of jejunal biopsy and gluten-free diets, may not necessarily have had coeliac disease. Furthermore, though the incidence of malignant complications was less in those treated with a gluten-free diet, the data was not adequate for statistical analysis. The purpose, then, of this present paper is fourfold. Firstly, to report the deaths observed in the original series of 202 patients published from this centre by Harris et al. (1967) after a further 10 years of surveillance. Secondly, to review with respect to malignancy all patients with a characteristic coeliac jejunal biopsy seen and followed in this unit to the end of 1972. Thirdly, to determine whether a gluten-free diet reduces the incidence of malignancy in this latter group. Finally, to ascertain whether patients who show a poor clinical response to gluten withdrawal are more prone to die from malignant complications than those individuals who experience an excellent response, and whether there is any support for the suggestion that malignancy itself may be responsible for the flat mucosa in some patients.

\section{Series I}

REVIEW OF 202 PATIENTS (Harris et al. 1967) Methods Two hundred and two patients with idiopathic steatorrhoea or coeliac disease originally followed up to the end of 1965 by Harris et al. (1967) were reviewed with respect to malignant complications up to the end of 1975 . Since the original report, 10 patients have been biopsied for the first time and shown to have flat biopsies, leaving 11 of the living patients not yet biopsied. Of these, six could not be traced and five have refused biopsy. Five further patients with coeliac disease alive and well in 1965 could not be traced. Thus 11 patients in all have not been traced, and are assumed to be living.

Results By the end of 1975 , the mean length of follow-up was 13.2 years, $7 \cdot 4$ years for those who had died and 18 years for those still living. Of the 20 further deaths during the last 10 years, 10 were due to malignant disease. The total number of deaths in the series was 97 of which 37 were due to cancer (Table 1). Necropsies were performed in 78

Table 1 Review of 202 patients with CD/IS: series I

\begin{tabular}{lll}
\hline & 1965 & 1975 \\
\hline Total deaths & 77 & 97 \\
Deaths due to malignancy & 27 & 37 \\
Patients with malignancy (living and dead) & 30 & 41 \\
Total malignancies & 32 & 43 \\
\hline
\end{tabular}

patients. The intestinal tract was involved in each of the four patients who developed a reticulum cell sarcoma. The details of the other 14 patients with lymphoma were given in the earlier report. In all, four patients of the 18 with lymphomas did not have involvement of the intestinal tract. Furthermore, four additional patients have cancer, but at the end of 1975 were still alive. Since two patients each had two separate primary tumours, the total number of malignancies in the series is 43 .

No further carcinomas of the oesophagus were encountered but one additional patient with carcinoma of the rectum and two with carcinoma of the pharynx were observed (Tables 1 and 2).

\section{Series II}

REVIEW OF 210 PATIENTS WITH BIOPSY-PROVEN COELIAC DISEASE

Methods These 210 patients included the 98 biopsied from among cases 1-149 studied in the report by Harris et al. (1967), together with all other patients with coeliac disease as defined by Cooke and Asquith (1974), seen subsequent to 1965 up to the end of 1972, and followed in the Nutritional and Intestinal Unit up to the end of 1974. The sex, age at the end of 1974, date of diagnosis, and the dietary status, whether gluten-free or normal diet, were recorded for each individual. Many patients 
Table 2 Instance of malignant neoplasms in 202 patients with $C D / I S$ : series I

\begin{tabular}{|c|c|c|c|c|c|c|}
\hline & \multicolumn{3}{|l|}{1965} & \multicolumn{3}{|l|}{1975} \\
\hline & Total & $I S$ & $C D$ & Total & $I S$ & $C D$ \\
\hline Lymphoma & 14 & 6 & 8 & 18 & 6 & 12 \\
\hline GIT cancer & 14 & 10 & 4 & 18 & 10 & 8 \\
\hline Oesophagus & 6 & 4 & 2 & 6 & 4 & 2 \\
\hline Stomach & 3 & 2 & 1 & 3 & 2 & 1 \\
\hline Tongue & 1 & $\mathbf{0}$ & 1 & 1 & $\mathbf{0}$ & 1 \\
\hline Colon* & 2 & 2 & $\mathbf{0}$ & 2 & 2 & $\mathbf{0}$ \\
\hline Rectum & 1 & 1 & 0 & 2 & 1 & 1 \\
\hline Anus & 1 & 1 & $\mathbf{0}$ & 1 & 1 & $\mathbf{0}$ \\
\hline Pharynx & 0 & $\mathbf{0}$ & $\mathbf{0}$ & 2 & 0 & 2 \\
\hline Pancreas & $\mathbf{0}$ & $\mathbf{0}$ & $\mathbf{0}$ & 1 & $\mathbf{0}$ & 1 \\
\hline Other malignancies & 4 & $\mathbf{0}$ & 4 & 7 & $\mathbf{0}$ & 7 \\
\hline Bronchus & 1 & $\mathbf{0}$ & 1 & 2 & $\mathbf{0}$ & 2 \\
\hline Ovary & 1 & 0 & 1 & 1 & 0 & 1 \\
\hline Skin & 1 & $\mathbf{0}$ & 1 & 1 & $\mathbf{0}$ & 1 \\
\hline Bladder & 0 & $\mathbf{0}$ & $\mathbf{0}$ & 1 & 0 & 1 \\
\hline Ac. myeloid leukaemia & 0 & $\mathbf{0}$ & $\mathbf{0}$ & 1 & $\mathbf{0}$ & 1 \\
\hline Unknown & 1 & 0 & 1 & 1 & 0 & 1 \\
\hline Total & 32 & 16 & 16 & 43 & 16 & 27 \\
\hline
\end{tabular}

* One was omitted in error from the previous review (Harris et al. 1967).

were started on a gluten-free diet and for various reasons either stopped or broke diet so completely that they have been included as taking a normal diet. Despite this, all such patients remained clinically well. All causes and dates of death were listed. Necropsies were performed on 39 of the 43 patients dying during the period under review. Of the remaining four, case 20 died of carcinoma of the oesophagus confirmed by biopsy, case 59 of lymphoma confirmed by laparotomy, case 81 of bronchopneumonia, and case 107 of carcinomatosis confirmed by lymph node biopsy.

Because the study covered a wide range of calendar years, cohort analysis was the method of choice. The Case-Pearson mortality tables were used as the basis for computing expected numbers of deaths (Case and Pearson, 1957). For each sex, the quinary-quinquennial rates were interpolated between both age-year groupings to produce an array of rates specific for age and calendar year. By applying the rates to comparable person-years at risk - that is, the years of survival contributed by each member of the series at a specific age in a specified year-the number of deaths that might be expected to occur during the period was computed for all causes, all malignancies, carcinoma of the oesophagus, and carcinoma of the pharynx. Because the cohort rates for lymphoma were not available, the expectation for this condition were determined by applying an annual rate (based on 1965 deaths) over the whole period. The resultant expectations were compared with the observed mortality and the statistical significance of the difference between them was assessed by use of the Poisson distribution.
The period of risk for each individual was taken from the date of diagnosis up to the end of 1974 or earlier death for patients on normal diet, and from the date of starting the diet up to the end of 1974 or death for those on a gluten-free diet. Patients who received a gluten-free diet but not immediately after diagnosis, were placed in the normal diet group before gluten withdrawal, after which they were put in the gluten-free group. The numbers of patients in the Tables refers to the final distribution between dietary groups.

For patients who had been treated with a glutenfree diet for at least one year, an attempt was made to assess their clinical response by taking an overall view of the progress of each patient after gluten withdrawal. In particular, improvement in well being, appetite, energy, and appearance of the stools, the lessening of abdominal discomfort and distension, reduction in the number of bowel actions, and the gain in weight were noted for each subject. In addition, the morphological response of the jejunal mucosa to gluten withdrawal was also recorded in these patients.

Results There were 94 males (aged at diagnosis from 1 to 72 years) and 116 females (aged from 2 to 73 years). Of these, at the end of the survey, 70 were receiving a normal diet, while 134 were taking a gluten-free diet for more than 12 months. The remaining six patients, who were all dead and who had taken a gluten-free diet for less than one year, were not classified with regard to their dietary status. One hundred and seventeen patients had an excellent clinical response having been on diet for a mean of 7.5 years (range two-21 years), while 17 had only a partial response after a mean of 8.1 years (range two-22 years) on diet. Of the 117 good clinical responders, further jejunal biopsies had been obtained from 74; morphological improvement had occurred in 68 . Of the 17 poor clinical responders, 12 had been re-biopsied with seven showing morphological improvement. Forty-three patients in series II had died from all causes when 20.82 deaths were expected, giving a highly significant difference when compared with the normal population $(P<$ 0.001 ). Of these deaths, 21 were due to malignant disease (Table 3). Seven additional patients had

Table 3 Patients with malignancy among 210 patients with $C D$ : series II

\begin{tabular}{lcl}
\hline & Dead & Alive \\
Lymphoma & & \\
\hline Reticulum cell sarcoma & 13 & 0 \\
Hodgkins disease & 0 & 1 \\
GIT cancer & 6 & 2 \\
Other malignancies & 2 & 4 \\
Total & 21 & 7 \\
\hline
\end{tabular}


developed tumours but were still alive at the time of review (Table 4). Thirteen died of reticulum cell sarcoma at an average age at death of 53.9 years, range 36-82 years (Table 5) and eight from carcinoma mean age 53.7 years, range 36-71 years (Table 6).

The duration of symptoms of coeliac disease before the onset of symptoms attributed to lymphoma averaged 26 years and the corresponding figure for carcinoma was 25.5 years. The mean duration of symptoms attributed to lymphoma was
7.6 months and to carcinoma 8.3 months respectively. Of the whole group of 21 patients dying with malignancy, 13 had been treated with a gluten-free diet for a mean period of 41 months. All seven who had been on a diet for longer than a year, mean 6.0 years, experienced a satisfactory clinical response initially. The subsequent deterioration of their health was presumed to be due to malignant complications. Of the six patients who had received a gluten-free diet for less than 12 months, only one

Table 4 Living patients with malignancies among 210 patients with coeliac disease

\begin{tabular}{|c|c|c|c|c|c|c|}
\hline CD no. & $\operatorname{Sex}$ & Present age (yr) & Diet & Time on diet $(y r)$ & Response to diet & Malignancy \\
\hline $\begin{array}{r}46 \\
47 \\
58 \\
104 \\
115 \\
119 \\
183\end{array}$ & $\begin{array}{l}\mathbf{M} \\
\mathbf{F} \\
\mathbf{F} \\
\mathbf{M} \\
\mathbf{F} \\
\mathbf{F} \\
\mathbf{F}\end{array}$ & $\begin{array}{l}69 \\
58 \\
79 \\
61 \\
56 \\
69 \\
80\end{array}$ & $\begin{array}{l}\text { ND } \\
\text { GFD } \\
\text { GFD } \\
\text { GFD } \\
\text { GFD } \\
\text { GFD } \\
\text { ND }\end{array}$ & $\begin{array}{r}-13 \\
19 \\
9 \\
8 \\
7 \\
-\end{array}$ & $\begin{array}{l}\text { Yes } \\
\text { No } \\
\text { Yes } \\
\text { Yes } \\
\text { Yes } \\
\end{array}$ & $\begin{array}{l}\text { Ca bronchus } \\
\text { Ca ovary* } \\
\text { Ca rectum } \\
\text { Hodgkins disease* } \\
\text { Ca breast*, ca ovary } \\
\text { Melanoma (eye) } \\
\text { Ca tongue }\end{array}$ \\
\hline
\end{tabular}

- Developed while taking normal diet.

GFD = patients treated with a gluten-free diet for longer than one year irrespective of clinical response: ND = patients taking a normal diet, plus those treated with a gluten free diet for less than one year.

Table 5 Deaths due to reticulosarcoma occurring among 210 patients with coeliac disease: series II

\begin{tabular}{|c|c|c|c|c|c|c|c|}
\hline$C D$ no. & Sex & $\begin{array}{l}\text { Age at death } \\
(y r)\end{array}$ & $\begin{array}{l}\text { Duration of CD } \\
\text { symptoms* }(y r)\end{array}$ & $\begin{array}{l}\text { JB before death } \\
(y r / m t h)\end{array}$ & $\begin{array}{l}G F D \\
(y r / m t h)\end{array}$ & $\begin{array}{l}\text { Response to } \\
G F D\end{array}$ & $\begin{array}{l}\text { Total duration of } \\
\text { symptoms attributed } \\
\text { to lymphoma (mth) }\end{array}$ \\
\hline 7 & $\mathbf{M}$ & 56 & 39 & 53 & - & - & 3 \\
\hline 18 & $\mathbf{M}$ & 65 & 61 & 5 & - & - & 8 \\
\hline 30 & $\mathbf{F}$ & 82 & 79 & 118 & 104 & Yes & 2 \\
\hline 36 & $\mathbf{M}$ & 55 & 12 & 93 & 4 & Yes & 6 \\
\hline 73 & $\mathbf{F}$ & 67 & 4 & 38 & 38 & Yes & 2 \\
\hline 94 & $\mathbf{F}$ & 38 & 35 & 4 & - & - & 6 \\
\hline 105 & $\mathbf{M}$ & 47 & 0 & 6 & 6 & No & 9 \\
\hline 138 & $\mathbf{F}$ & 36 & 6 & 6 & 6 & No & 24 \\
\hline 139 & $\mathbf{M}$ & 39 & 36 & 0 & 3 & No & 9 \\
\hline 178 & $\mathbf{F}$ & 57 & 17 & 16 & 14 & Yes & 1 \\
\hline 188 & $\mathbf{F}$ & 54 & 15 & 1 & 1 & No & 3 \\
\hline
\end{tabular}

*Duration of symptoms before symptoms attributable to lymphoma.

Table 6 Deaths due to carcinoma occurring among 210 patients with coeliac disease: series II

\begin{tabular}{|c|c|c|c|c|c|c|c|c|}
\hline$C D$ no. & Sex & $\begin{array}{l}\text { Age at death } \\
(y r)\end{array}$ & $\begin{array}{l}\text { Duration of } \\
\text { CD symptoms } \\
(y r)\end{array}$ & $\begin{array}{l}\text { JB before } \\
\text { death } \\
\text { (yr/mth) }\end{array}$ & $\begin{array}{l}G F D \\
(y r / m t h)\end{array}$ & $\begin{array}{l}\text { Response to } \\
\text { GFD }\end{array}$ & $\begin{array}{l}\text { Total duration of } \\
\text { symptoms attributec } \\
\text { to carcinoma (mth) }\end{array}$ & $\begin{array}{l}\text { Site of } \\
\text { d carcinoma }\end{array}$ \\
\hline $\begin{array}{r}5 \\
20 \\
25 \\
34 \\
86 \\
92 \\
107 \\
135\end{array}$ & $\begin{array}{l}\mathbf{M} \\
\mathbf{M} \\
\mathbf{M} \\
\mathbf{F} \\
\mathbf{M} \\
\mathbf{M} \\
\mathbf{M} \\
\mathbf{F}\end{array}$ & $\begin{array}{l}46 \\
68 \\
45 \\
53 \\
58 \\
71 \\
36 \\
53\end{array}$ & \begin{tabular}{r|r|}
43 & \\
38 \\
40 \\
23 \\
16 \\
18 \\
2 \\
24
\end{tabular} & $\begin{array}{ll}9 & \\
3 & 6 \\
4 & 6 \\
8 & 6 \\
& 4 \\
9 & 3 \\
1 & 0 \\
7 & 6\end{array}$ & $\begin{array}{l}\overline{-} \\
\overline{4} \\
9 \\
\overline{8} \\
\begin{array}{l}10 \\
-\end{array}\end{array}$ & $\begin{array}{l}\overline{-} \\
\overline{Y e s} \\
\text { Yes } \\
\overline{Y e s} \\
\text { Yes } \\
-\end{array}$ & $\begin{array}{r}5 \\
18 \\
2 \\
18 \\
6 \\
8 \\
5 \\
4\end{array}$ & $\begin{array}{l}\text { Pharynx } \\
\text { Oesophagus } \\
\text { Oesophagus } \\
\text { Bladder } \\
\text { Stomach } \\
\text { Pharynx } \\
\text { Unknown } \\
\text { Rectum }\end{array}$ \\
\hline
\end{tabular}

*Duration of symptoms before symptoms attributable to carcinoma. 
showed an adequate clinical response (for some purposes of data analysis these particular patients were grouped with those who had always taken a normal diet).

The onset of malignancy was the event which led to the diagnosis of coeliac disease in seven patients, six with reticulum cell sarcoma (cases 59, 94, 105, $138,139,188)$ and case 86 with carcinoma of the stomach. Case 105 did not complain of any symptoms until nine months before death when they were considered to be due to malignant disease. A jejunal biopsy carried out six months before death was consistent with coeliac disease and necropsy performed within one hour of death revealed that the mucosa of the small intestine throughout the length was flat with deposits of reticulum cell sarcoma in the mesenteric lymph nodes and liver but none in the bowel itself. On the other hand, the other six patients in this group had had symptoms from between six and 36 years which could have been attributed to coeliac disease. For example, case 139 was treated at the Children's Hospital Birmingham as a coeliac and, although lost to follow-up until his final illness, stated that he had never felt really well and had been prone to gastrointestinal upsets. Case 188 had a macrocytic anaemia for 15 years: in addition, subsequent investigations of her relatives revealed a sister with coeliac disease that had previously been unsuspected.

When deaths from all malignancies were analysed irrespective of the diet that was taken a statistically significant increase occurred in deaths from cancer both in the whole series and in men and women separately (Table 7). An increase was noted in

Table 7 Deaths due to malignancy among 210 patients with coeliac disease: (series II)

\begin{tabular}{llll}
\hline & Expected & Observed & P \\
\hline Total group (210) & & & \\
All malignancies & 5.048 & 21 & $<0.001$ \\
Reticulum cell sarcoma & 0.114 & 13 & $<0.001$ \\
Ca oesophagus & 0.098 & 2 & $<0.01$ \\
Ca pharynx & 0.027 & 2 & $<0.001$ \\
Men (94) & & & \\
All malignancies & 2.878 & 12 & $<0.001$ \\
Reticulum cell sarcoma & 0.062 & 6 & $<0.001$ \\
Ca oesophagus & 0.053 & 2 & $<0.01$ \\
Ca pharynx & 0.013 & 2 & $<0.001$ \\
Women (116) & & & $<0.001$ \\
All malignancies & 2.170 & 9 & $<0.001$ \\
Recticulum cell sarcoma & 0.052 & 7 & NS \\
Ca oesophagus & 0.045 & 0 & NS \\
Ca pharynx & 0.014 & 0 & \\
\hline
\end{tabular}

deaths from reticulum cell sarcoma in men and women and in oesophageal and pharyngeal cancer in men.

Patients taking a normal diet were at greater risk of developing a malignant tumour than the popula- tion as a whole $(\mathrm{P}<0.05)$ (Table 8). However, seven tumours occurred in those patients on a gluten-free diet, a figure significantly in excess of that expected, all in subjects who had shown a good clinical response. Deaths from reticulum cell sarcoma both in those on a normal diet and in those on a gluten-free diet were also significantly increased.

Table 8 Deaths due to malignancy in coeliac disease in relation to dietary history: (series II)

\begin{tabular}{lrlll}
\hline & No. & Exprited & Observed & P \\
\hline All malignancies & & & & \\
$\quad$ All GFD & 134 & 1.259 & 7 & $<0.001$ \\
$\quad$ Responders & 117 & 1.116 & 7 & $<0.001$ \\
$\quad$ Poor responders & 17 & 0.143 & 0 & NS \\
ND & 70 & 3.787 & 8 & $<0.05$ \\
Reticulum cell sarcoma & & & & \\
All GFD & 134 & 0.038 & 4 & $<0.001$ \\
$\quad$ Responders & 117 & 0.031 & 4 & $<0.001$ \\
$\quad$ Poor responders & 17 & 0.007 & 0 & NS \\
ND & 70 & 0.759 & 4 & $<0.001$ \\
Ca oesophagus & & & & \\
All GFD & 134 & 0.030 & 1 & $<0.05$ \\
$\quad$ Responders & 117 & 0.024 & 1 & $<0.05$ \\
$\quad$ Poor responders & 17 & 0.006 & 0 & NS \\
ND & 70 & 0.067 & 1 & NS \\
Ca pharynx & & & & $<0.01$ \\
All GFD & 134 & 0.007 & 1 & $<0.01$ \\
$\quad$ Responders & 117 & 0.006 & 1 & NS \\
Poor responders & 17 & 0.001 & 0 & $<0.05$ \\
ND & 70 & 0.020 & 1 & \\
\hline
\end{tabular}

No deaths from either carcinoma or reticulum cell sarcoma were encountered in patients who had shown a suboptimal response to gluten withdrawal. Furthermore, of the six patients who had been treated for an average of 11 years with a gluten-free diet and who had shown good clinical response but whose jejunal morphology had not improved, none developed malignancy.

A further analysis of data was carried out in which all patients who had been treated with a gluten-free diet for longer than 12 months were considered together irrespective of their clinical response. Those individuals who had taken the diet for less than 12 months were grouped with those patients who had been having a conventional diet (Table 9). In both groups there was an excess of deaths from all malignancies and lymphomas when compared with the general population. In the Figure series I and II have been combined in respect to the deaths from carcinoma, lymphoma, or other causes and including all patients seen to the end of 1975 .

\section{Discussion}

Harris and his colleagues (1967) considered that their series of patients with idiopathic steatorrhoea and coeliac disease (series I) were a homogeneous group 
Table 9 Deaths from malignancies in coeliac disease: series II

\begin{tabular}{|c|c|c|c|c|}
\hline & No. & Expected & Observed & $\mathbf{P}$ \\
\hline $\begin{array}{l}\text { All malignanci } \\
\text { All GFD } \\
\text { ND }\end{array}$ & $\begin{array}{r}134 \\
76\end{array}$ & $\begin{array}{l}\mathbf{1} \cdot 259 \\
\mathbf{3} \cdot 790\end{array}$ & $\begin{array}{r}7 \\
14\end{array}$ & $\begin{array}{l}<0.001 \\
<0.001\end{array}$ \\
\hline $\begin{array}{l}\text { Reticulum cell } \\
\text { All GFD } \\
\text { ND }\end{array}$ & $\begin{array}{r}134 \\
76\end{array}$ & $\begin{array}{l}0.038 \\
0.760\end{array}$ & $\begin{array}{l}4 \\
9\end{array}$ & $\begin{array}{l}<0.001 \\
<0.001\end{array}$ \\
\hline $\begin{array}{l}\text { Ca oesophagus } \\
\text { All GFD } \\
\text { ND }\end{array}$ & $\begin{array}{r}134 \\
76\end{array}$ & $\begin{array}{l}0.030 \\
0.067\end{array}$ & $\begin{array}{l}1 \\
1\end{array}$ & $\begin{array}{c}<0.05 \\
\text { NS }\end{array}$ \\
\hline $\begin{array}{l}\text { Ca pharynx } \\
\text { All GFD } \\
\text { ND }\end{array}$ & $\begin{array}{r}134 \\
76\end{array}$ & $\begin{array}{l}0.007 \\
0.020\end{array}$ & $\begin{array}{l}1 \\
1\end{array}$ & $\begin{array}{l}<0.01 \\
<0.05\end{array}$ \\
\hline
\end{tabular}

GFD = patients treated with a gluten-free diet for longer than one year irrespective of clinical response. $\mathrm{ND}=$ patients taking a normal diet, plus those treated with a gluten-free diet for less than one year

both on clinical, laboratory, and pathological evidence. Their contention is supported by the observation that of the 21 living patients with idiopathic steatorrhoea in 1965 , a further 10 have had a jejunal biopsy performed and in each the characteristic appearance of coeliac disease was seen. This series has afforded an opportunity to keep a group of patients with coeliac disease under continued surveillance and, in the 10 years since 1965,10 more patients have developed malignancies. Of these 10 malignancies, four were reticulum cell sarcoma, totalling 18 over the years for the whole group. It is also significant that, of the 43 malignancies encountered, 32 (14 reticulum cell sarcomas and 18 carcinomas) involved the intestinal tract. Such an incidence of malignancy is, of course, much higher than that expected from any control population. Between 1941 and 1975, of the total of 97 deaths, 37 have been due to malignant disease, leaving little doubt that, in this series of 202 patients, there has been an increase in deaths from cancer, particularly reticulum cell sarcoma and gastrointestinal cancer.

To remove any doubt as to whether those patients who had not undergone jejunal biopsy in the earlier series (series I) biased the statistics on the incidence of malignancy, an analysis of all patients with coeliac disease proven by biopsy up to the end of 1972 , and followed up on the unit, was undertaken (series II). The date of diagnosis by jejunal biopsy, which represents a precise event, was taken as the date of entry into the series and from which the period of observation was measured. To extend the analysis backward in time to the date of first symptoms, for example, would introduce an element of bias for two reasons; first, it is often impossible to obtain accurate information from patients of events occurring several years before clinical diagnosis and secondly, and perhaps more important, the series represents a selected sample in that all patients are alive at the date of diagnosis. Thus, expected deaths computed for a 'symptomatic' period could never be matched by observation. The analysis confirmed that there is a significantly increased risk of malignancy in coeliac disease and, in this group, malignancy was the cause of 21 of the 43 deaths encountered. Again, the incidence of lymphoma, in particular reticulum cell sarcoma, was increased. Though no further oesophageal cancers had been seen since the publication of the earlier series (series I) and only two of the original six had been biopsied, the incidence was still significantly increased. Two patients with carcinoma of the pharynx provided further evidence of the liability of the upper gastrointestinal tract to develop malignancy. The association noted between the Epstein-Barr virus and nasopharyngeal carcinoma is of interest in this

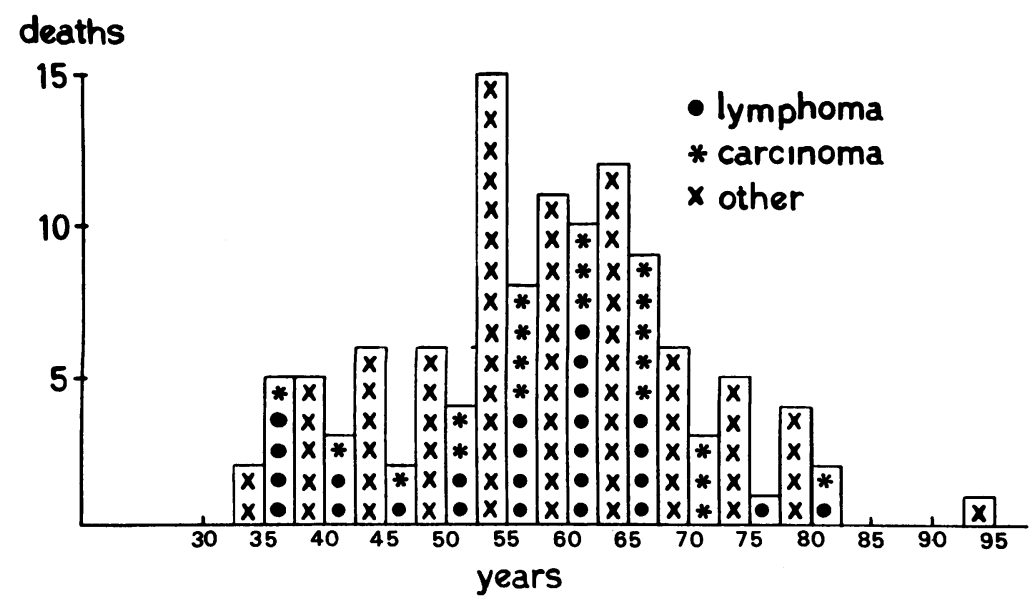

Figure Age at death from carcinoma, lymphoma, or other causes occurring in series I and II and, in addition, including all patients seen to the end of 1975. 
respect (Epstein, 1970; Klein, 1971), suggesting the possibility that oncogenic viruses might play a part in the occurrence of this tumour in coeliac disease. No patients in this series developed carcinoma of the duodenum, but two were seen in consultation in the hospital, one who had been on a gluten-free diet for five years and the other presenting as intestinal obstruction.

Consideration must be given to those patients who presented with malignancy, had a flat biopsy, and died within a short period as to whether they can be included as having coeliac disease or whether the flat mucosa represents the response to malignancy, as postulated by Brunt et al. (1969) and Barry and Read (1973). Only one of the seven patients in this category had a relatively short history; the other six had long histories compatible with coeliac disease as long as 36 years and averaging 21.2 years, even though it was the onset of malignant disease that brought them to diagnosis. The occurrence of asymptomatic patients with flat biopsies is now established. In a survey of first degree relatives of coeliac patients $11 \%$ were discovered to have the characteristic jejunal biopsy and one-third of these were without symptoms (Stokes et al., 1976). The lack of any appreciable incidence of flat biopsies among patients with carcinoma (Girdwood, 1964; Fu and Perzin, 1972; Gilat et al., 1973) does not support the suggestion that cancer can be responsible for the appearance of the jejunal biopsy. Thus, Petreshock et al. (1975) in reporting the occurrence of carcinoma of the jejunum in a patient who had been successfully treated for 13 years on a gluten-free diet pointed out that the majority of the 15 patients reported with this complication had a long history, usually of more than 30 years. It is also pertinent that three of our patients on a gluten-free diet had shown virtually complete histological remission in their jejunal biopsies at the time that their malignancy made its appearance, two with reticulum cell sarcoma (Cooke et al., 1969) and one with acute myeloid leukaemia, while at least three of those who came to necropsy showed a virtual absence of flat mucosa when the whole length of the small intestine was examined under the dissecting microscope and then randomly sectioned. However, since a flat mucosa can be produced in dermatitis herpetiformis (which has a close association with coeliac disease) by feeding gluten (Weinstein, 1974), the possibility that the metabolic derangements of malignancy may be the necessary factor to produce flat biopsies in patients who already bear the coeliac trait albeit not having until then the characteristic biopsy cannot be ruled out. It is our present view that patients presenting with malignancy and with findings compatible with coeliac disease should be accepted as having coeliac disease which has been complicated by malignancy.

When considering the effect of a particular treatment in patients with a relatively rare chronic disease, sufficient numbers for analysis must be gathered over many years and observed for a long period of time for adequate assessment. Thus, for historical and indeed ethical reasons, the series could not be randomised with respect to diet and caution must therefore be exercised in evaluating the results of gluten withdrawal. Thus, person-years at risk rather than individuals have been allocated to categories of diet. Thus, a patient who remained on a normal diet for some years after diagnosis before receiving a gluten-free diet contributes the relevant 'years at risk' to each group; a patient must be alive to be considered for entry to the gluten-free diet group. Any deaths computed for the period between diagnosis and the start of gluten-free therapy could not be matched by observation.

The majority of patients with coeliac disease show dramatic improvement in all respects when placed on a gluten-free diet. It may therefore be asked whether they are also protected from developing malignancy. Austad et al. (1967) suggested that lymphoid hyperactivity in the jejunal mucosa of patients with coeliac disease may give rise to an increased incidence of malignancy, presumably on the grounds that the more mitoses occurring the greater the chance of mutant cells arising. It is also pertinent that there is a significant reduction of cells after gluten withdrawal (Holmes et al., 1974), which might suggest therefore a lessened risk of malignancy. Furthermore, carcinogens (Wattenberg, 1966) might be more easily detoxicated by the coeliac mucosa and its enzymes when restored to normality by a gluten-free diet. There is no evidence in our present data to suggest that those with a poor response to a gluten-free diet are more liable to develop malignant complications as has been suggested by Barry and Read (1973). However, epithelial cell turnover studies were not carried out, so that the patients in this series with a poor response may not be strictly comparable with those reported by Barry and Read (1973).

This study has not provided evidence that a glutenfree diet is effective in preventing malignant complications. It is perhaps optimistic to expect to demonstrate any significant effect of a gluten-free diet in patients who have already been exposed to an oncogenic stimulus for many years, probably since birth. It is possible that for patients with coeliac disease their life experience before gluten withdrawat may have already determined their ultimate fatel Furthermore, while a gluten-free diet may preven. malignant complications in some of the younger 
patients and even prolong their lives, the histogram of all the deaths shows that patients with malignancy on the whole are dying in the same age range as those who are dying of other causes. Thus, a gluten-free diet may not materially prolong life but may alter the cause of death. While the evidence for coeliac disease harbouring malignant potential is undoubtedly very strong, it will be some years before it will be possible to provide evidence that a glutenfree diet decreases this risk or increases the expectation of life. At present to achieve this, one might speculate that such protection will necessitate lifelong abstinence from gluten. It may be that if a glutenfree diet does offer any protection against malignancy it will become apparant only in an analysis of a large group of patients who have been on diet since childhood.

\section{References}

Austad, W. I., Cornes, J. S., Gough, K. R., McCarthy, C. F., and Read, A. E. (1967). Steatorrhea and malignant lymphoma: the relationship of malignant tumors of lymphoid tissue and celiac disease. American Journal of Digestive Diseases, 12, 475-490.

Barrett, G. M. (1964). Coeliac disease and malignant change. (Letter.) Lancet, 1, 723.

Barry, R. E., and Read, A. E. (1973). Coeliac disease and malignancy. Quarterly Journal of Medicine, 42, 665-675.

Barry, R. E., Baker, P., and Read, A. E. (1973). The clinical presentation. Clinics in Gastroenterology, 3, 55-69.

Best, C. N., and Cook, P. B. (1961). Case of mesenteric reticulosarcoma associated with gluten-sensitive steatorrhoea. British Medical Journal, 2, 496-498.

Bjerkelund, C. J. (1950). Symptomatic sprue: a study of six verified cases. Acta Medica Scandinavica, 137, 130-149.

Brunt, P. W., Sircus, W., and MacLean, N. (1969). Neoplasia and the coeliac syndrome in adults. Lancet, 1, 180184.

Case, R. A. M., and Pearson, J. T. (1957). Tables for comparative composite cohort analysis. In Cancer Statistics for England and Wales, 1901-1955. Edited by A. M. McKenzie. (General Register Office, Studies on Medical Population Subjects, No. 13.) H.M.S.O., London.

Cooke, W. T. and Asquith, P. (1974). Introduction and definition of coeliac disease. Clinics in Gastroenterology, 3, 3-10.

Cooke, W. T., Thompson, H., and Williams, J. A. (1969). Malignancy and adult coeiiac disease. Gut, 10, 108-111.

Creamer, B. (1964). Malignancy and the small-intestinal mucosa. British Medical Journal, 2, 1435-1436.

Epstein, M. A. (1970). Aspects of the EB virus. Advances in Cancer Research, 13, 383-411.

Fairley, N. H., and Mackie, F. P. (1937). The clinical and biochemical syndrome in lymphadenoma and allied diseases involving mesenteric lymph nodes. British Medical Journal, 1, 375-380.

Fischer, R. A., Rosoff, B. M., Altsuler, J. H., Thayer, W. R., Jr., and Spiro, H. M. (1965). Disacchariduria in malignant disease. Cancer, 18, 1278-1284.
French, J. M., Hawkins, C. F., and Smith, N. (1957). The effect of a wheat-gluten-free diet in adult idiopathic steatorrhoea. Quarterly Journal of Medicine, 26, 481-499.

Friedlander, P. H., and Gorvy, V. (1955). Steatorrhoea. British Medical Journal, 2, 809-812.

Fu, Y. S., and Perzin, K. H. (1972). Lymphosarcoma of the small intestine: a clinicopathologic study. Cancer, 29, 645-659.

Gilat, T., Fischel, B., Danon, J., and Loewenthal, M. (1973). Morphology of small bowel mucosa in malignancy. Digestion, 7, 147-155.

Girdwood, R. H. (1964). Malignancy and the small intestinal mucosa. (Letter.) British Medical Journal, 2, 1592.

Golden, R. (1936). The small intestine and diarrhea. American Journal of Roentgenology, 36, 892-901.

Gough, K. R., Read, A. E., and Naish, J. M. (1962). Intestinal reticulosis as a complication of idiopathic steatorrhoea. Gut, 3, 232-239.

Harris, O. D., Cooke, W. T., Thompson, H., and Waterhouse, J. A. H. (1967). Malignancy in adult coeliac disease and idiopathic steatorrhoea. American Journal of Medicine, 42, 899-912.

Harrison, H. E., Harrison, H. C., Tompsett, R. R., and Barr, D. P. (1947). Potassium deficiency in a case of lymphosarcoma with the sprue syndrome. American Journal of Medicine, 2, 131-143.

Holmes, G. K. T., Asquith, P., Stokes, P. L., and Cooke, W. T. (1973). Cellular infiltrate of jejunal biopsies in adult coeliac disease in relation to gluten withdrawal. Gut, 15, 278-28.3.

Klein, G. (1971). Immunological aspects of Burkitt's lymphoma. Advances in Immunology, 14, 187-250.

Missen, G. A. K. (1966). Intestinal malignant lymphoma and cerebellar cortical degeneration complicaring idiopathic steatorrhoea: report of a case with a review of the literature. Guy's Hospital Reports, 115, 359-385.

Oehler, V. (1953). Sprue. Gastroenterologix, 79, 257-282.

Petreshock, E. P., Pessah, M., and Menachemi, E. (1975). Adenocarcinoma of the jejunum associated with nontropical sprue. American Jourral of Digestive Diseases, 20, 796-802.

Read, A. E. (1976). Personal communication.

Salvesen, H. A., and Kobro, M. (1939). Symptomatic sprue. Acta Medica Scandinavica, 102, 277-294.

Scudamore, H. H. (1961). Observations on secondary malabsorption syndromes of intestinal origin. Annals of Internal Medicine, 55, 433-447.

Sleisenger, M. H., Almy, T. P., and Barr, D. P. (1953). The sprue syndrome secondary to lymphoma of the small bowel. American Journal of Medicine, 15, 666-674.

Spracklen, F. (1963). Reticulosis of the small bowel as a late complication of idiopathic steatorrhoea. Proceedings of the Roval Society of Medicine, 56, 167-168.

Stokes, P. L., Ferguson, R., Holmes, G. K. T., and Cooke, W. T. (1976). Familial aspects of coeliac disease. Quarterly Journal of Medicine. (In press).

Upshaw, C. B., Jr., and Pollard H. M. (1957). The sprue syndrome associated with intra-abdominal lymphoblastoma. Gastroenterology, 33, 104-112.

Wattenberg, L. W. (1966). Carcinogen-detoxifying mechanisms in the gastrointestinal tract. Gastroenterology, 51, 932-935.

Weinstein, W. M. (1974). Latent celiac sprue. Gastroenterology, 66, 489-493. 